\title{
Assessment of the care process with orthotics, prosthetics and special materials
}

\author{
Avaliação do processo de cuidado com órteses, próteses e materiais especiais \\ Evaluación del proceso de cuidado con ortesis, prótesis y materiales especiales
}

\section{Clayton dos Santos Moraes', Eliane Goldberg Rabin", Karin Viégas'}

' Universidade do Vale do Rio dos Sinos. Porto Alegre, Rio Grande do Sul, Brazil.

"Universidade Federal de Ciências da Saúde de Porto Alegre. Porto Alegre, Rio Grande do Sul, Brazil.

\section{How to cite this article:}

Moraes CS, Rabin EG, Viégas K. Assessment of the care process with orthotics, prosthetics and special materials. Rev Bras Enferm [Internet]. 2018;71(3):1099-105. DOI: http://dx.doi.org/10.1590/0034-7167-2017-0031

Submission: 03-13-2017 Approval: 06-11-2017

\begin{abstract}
Objective: to assess potential failures in the care process with orthotics, prosthetics and special materials in a high-complexity hospital. Method: an intervention study conducted from March to October 2013. This process was assessed with the Failure Mode and Effects Analysis (FMEA) service tool. The data were analysed according to the risk and the corrective measures were defined. Results: no failure was classified as high risk and the corrective measures indicated as low and moderate risk had the following improvement initiatives suggested: standardize the material records in the information system; create a specific form to require materials; hire specialized technical personnel and create a continuous education program. Conclusion: all the suggested initiatives were implemented and helped to reduce the assistance risks for patients due to failures in this process. The actions increase safety levels and provide higher quality of service.
\end{abstract}

Descriptors: Assessment of Processes; Analysis and Performance of Tasks; Quality Assurance in Health Care; Management of Materials in Hospitals; Quality Control.

\section{RESUMO}

Objetivo: avaliar as falhas potenciais, no processo de trabalho do cuidado com órteses, próteses e materiais especiais em um hospital de alta complexidade. Método: estudo de intervenção realizado de março a outubro de 2013. O processo foi avaliado utilizando a ferramenta de Análise de Modos de Falhas e Efeitos do tipo serviço. Os dados foram analisados conforme o risco e foram definidas as medidas corretivas. Resultados: nenhuma falha foi classificada de alto risco e as medidas corretivas apontadas como de baixo e moderado risco tiveram propostas de ações de melhoria, como: padronização dos cadastros de materiais no sistema de informação; criação de um formulário específico para a solicitação de material; contratação de pessoal técnico especializado e criação de um programa de educação permanente. Conclusão: todas as ações propostas foram implantadas e auxiliaram na redução do risco assistencial aos pacientes por falhas neste processo, aumentando os níveis de segurança e proporcionando maior qualidade no serviço. Descritores: Avaliação de Processos; Análise e Desempenho de Tarefas; Garantia da Qualidade dos Cuidados de Saúde; Administração de Materiais no Hospital; Controle de Qualidade.

\section{RESUMEN}

Objetivo: evaluar las fallas potenciales en el proceso de trabajo del cuidado con ortesis, prótesis y materiales especiales en un hospital de alta complejidad. Método: estudio de intervención realizado de marzo a octubre de 2013 . El proceso fue evaluado utilizando la herramienta de Análisis del Modo y Efecto de Fallas del tipo servicio. Los datos fueron analizados conforme el riesgo y se definieron las medidas correctivas. Resultados: ninguna falla fue clasificada como alto riesgo y las medidas correctivas apuntadas como de bajo y moderado riesgo han tenido propuestas de acciones de perfeccionamiento: estandarización de los registros de materiales en el sistema de información; creación de un formulario específico para la solicitud de material; contratación de personal técnico especializado y creación de un programa de educación permanente. Conclusión: todas las acciones propuestas fueron implantadas y ayudaron en la reducción del riesgo asistencial a los pacientes por fallas en este proceso, aumentando los niveles de seguridad y proporcionando más calidad en el servicio.

Descriptores: Evaluación de Procesos; Análisis y Rendimiento de Tareas; Garantía de Calidad de los Cuidados de Salud; Administración de Materiales en Hospitales; Control de Calidad.

\section{CORRESPONDING AUTHOR Karin Viégas E-mail: kviegas@gmail.com}




\section{INTRODUCTION}

Hospital institutions work daily with a great volume of patient care and this demands high complexity hospital procedures and services, which include surgical centre units, tests, digestive endoscopy and colonoscopy, hemodynamic monitoring, diagnostic imaging and intense therapy. These processes often use orthotics, prosthetics and special materials (OPSM). Therefore, quality policies and safety of patients are essential to reduce both failure probability and failure risks in the working process. These policies increase trust and assistance quality ${ }^{(1)}$.

Several stages of the process can be decisive to properly assist the patient. Any failure in one of these stages may cause lack of OPSM and directly and negatively impact the patient's health condition. The complexity of this process demands from the multi-professional team an accurate performance and a very specific technical-scientific knowledge. It is important to highlight that nurses manage the administrative processes in specific areas ${ }^{(2)}$.

The working process of managing OPSM is considered a high cost for the hospital. To use OPSM to assist patients, it is necessary to have health and information technology professionals so that the processes are thoroughly designed and rigorously followed for the control of admission, preparation, use, devolution and invoicing of these materials.

Specific health care such as surgical procedures which use OPSM are only discussed among doctors, and it can lead to system failure. In case the process fails at any stage, the operation cost remains active because human, technological and logistic resources are still installed. In these situations, these would be the cost of idleness of the operating room, inadequate preparation of the patient and family, etc. The OPSM represent between 15 to $25 \%$ of all expenses resulting from a service. Therefore, this process becomes almost unmanageable, especially if we consider the current volume of OPSM used in hospital institutions ${ }^{(3)}$.

In 2005, the World Alliance for Patient Safety, acknowledging the need to reduce harm caused by errors within the surgical environment, established an increase in quality standards by taking four initiatives. They were: prevention of surgical site infection, safe anaesthesia, safe surgical teams and indicators of surgical assistance. These initiatives based the campaign of the World Health Organisation named "Safe Surgery Saves Lives"(4).

Driven by the practical need to improve and control quality in the processes regarding patient care, some tools created and widely used by the hospital industry have been implemented and spread in hospitals, such as the Failure Mode and Effects Analysis (FMEA). This tool is an excellent methodology used to detect known or potential failures mode in products or processes. It allows a better planning of initiatives before they reach the final client, i.e., analyse and foresee the incidence of in-hospital adverse events. The FMEA can be of four types: products used to analyse deficiencies in the development program of a specific product, before it is produced; systems set to identify failures in systems and subsystems prior to developing a project; processes focused on failure modes caused by deficiencies in the manufacturing and assembly processes; services used to identify failure modes of processes and systems before it reaches the final consumer ${ }^{(7)}$.

\section{OBJECTIVE}

To assess potential failures in the care process of OPSM using the FMEA methodological tool in a high-complexity hospital in the city of Porto Alegre, Rio Grande do Sul State.

\section{METHOD}

\section{Ethical Aspects}

The present study was conducted following the resolution of the National Health Council of Brazil and approved by the ethics and research committees of the institutions involved.

\section{Research design, place and period}

Intervention study performed in a large private hospital of high complexity in the city of Porto Alegre, Rio Grande do Sul State, Brazil, from March to October 2013. The main station regulates the use of OPSM and it comprises three centres: pre-operative authorization centre; receipt and devolution of materials; and post-operative authorization centre. Although there is an OPSM centre, this process exceeds the limits of the centre's operations and extends to other departments such as surgical scheduling, materials and sterilization centre, satellite pharmacies of the surgical centre and care areas.

\section{Population and Sample}

A multi-professional team was assembled to develop the assessment of the process (assessment group-AG). The team had six leaders engaged in supporting the management of OPSM: pre-operative authorization centre; receipt and devolution of materials; surgical scheduling; materials and sterilization centre; information technology and one representative for the care areas of the surgical centre, hemodynamic and endoscopy. The professionals were chosen according to their overall view of each specific centre and the entire institution in the process of OPSM.

\section{Study protocol}

The method known as FMEA, originally developed in the engineering field, was adapted to be proactively used in the health care process. It also used a multidisciplinary and experienced team engaged in the process, named assessment group (AG) $)^{(9-10)}$.

The AG has a score to determine potential vulnerabilities in the care process and assess its potential effects on the service provided to patients. Seven meetings were held to assess the process, once a week, within working hours, lasting one hour each. In these meetings, we addressed the methodological aspects of the FMEA, the OPSM process as well as detailed the FMEA tool, which allows us to define initiatives to potential failures found. All debates and suggestions deriving from the meetings were recorded and transcribed. 


\section{Analysis of results}

To analyse the information from each stage of the OPSM working process, potential causes and the risk rate were calculated by multiplying the gravity analysis parameters (G), the probability occurrence $(\mathrm{O})$ and the possibility of detection (D). The G, O and D scales were adapted to the reality of the study at hand to calculate the risk rate ${ }^{(7)}$.

We created risk indexes $(R=G \times O x D)$ for every stage of the process to analyse each value. This generated a scale that ranges from 1 to 1000 points, i.e., low risk (1 to 135 points), moderate risk (136 to 500 points) and high risk (501 to 1000). After prioritizing the risks, corrected measures were defined for each stage of the process. Afterwards, the risk was recalculated. Whenever the recalculated risk is less than 500 points, the action and correction will be named implemented initiatives ${ }^{(7)}$.

\section{RESULTS}

The first initiative taken by the assessment group was the review of the OPSM working process, through the detailed flow chart analysis. The results obtained from this review as well as designing and describing the analysed stages (which were changed and are represented in the flow chart by the dark diagrams) are in Figure 1.

As of the review of the OPSM flow chart of the institution, the AG proceeded to the analysis of the stages related to Surgical Scheduling, Pre-Authorization Areas, Care Areas and Logistic Areas, looking for failures that would determine care risk for the patient. All the analysed stages presented at least one mode of potential failure, totalling 16 failures and none of high risk.

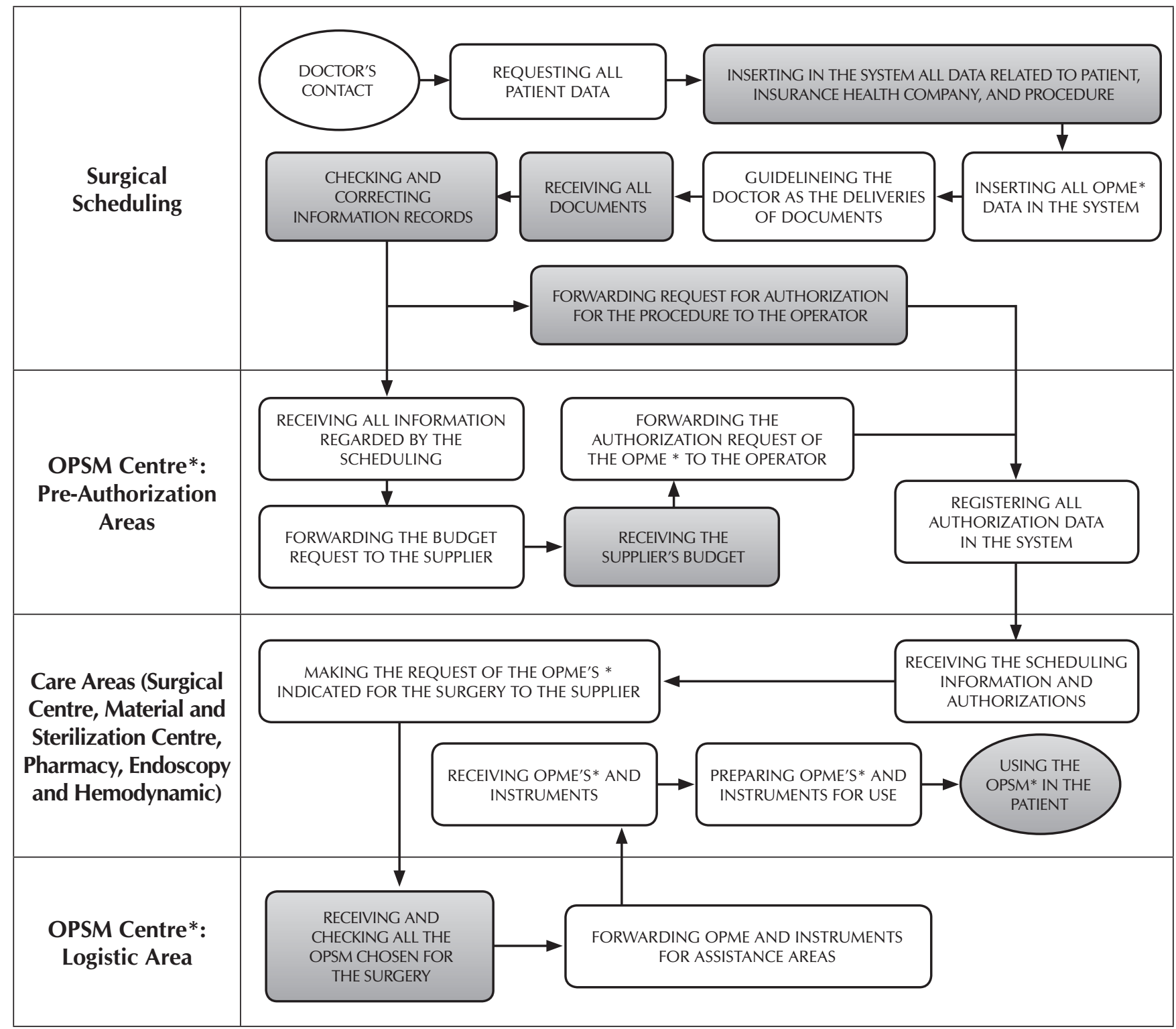

Note: *Orthotics, Prosthetics and Special Materials.

Figure 1 - Reviewed flow chart of the Orthotics, Prosthetics and Special Materials process of a high complexity hospital in the city of Porto Alegre, Rio Grande do Sul State, Brazil, 2014 


\section{The first stage of the process: surgical scheduling}

Five potential failure modes were found during the assessment of the eight stages conducted by the surgical scheduling centre. The first stage described by the AG was receiving the medical contact, whose failure mode was the lack of technical know-how, creating the possibility of using incorrect material for the surgeries. This is caused by lack of knowledge of the physician and the scheduling agent $(R=360)$. The initiatives implemented to reduce risks were standardizing the names of materials and hiring technical professional with experience in special materials, for them to conduct the administrative activity in the scope of surgical scheduling.

The second staged analysed by the AG was the request for all patient data provided by the attending physician at the time of the appointment. This failure mode is explained by incomplete or incorrect data, whose potential effects are the lack of authorization for the procedure ( $R=288$ points) and absence of the correct materials for the surgery $(R=200$ points). The causes related to these effects were the lack of knowledge of the physician and the scheduling assistant. A feasible alternative to reduce the incidence of this failure and its potential effects was to create a standard form for requesting surgical scheduling.

The next stage to be analysed by the AG was the input of all data, health plan and surgical procedure of the patient in the institution's computer system. It presented the failure modes of incomplete or incorrect data with two potential effects: (a) lack of authorization for the procedure ( $R=108$ points) and (b) absence of the correct materials for the surgery ( $R=180$ points). The potential causes created by (a) and (b) were inconsistent data provided by the physician and typing errors by the scheduling assistant. The initiatives taken to minimize potential risks were the review of all data before and after inserting them in the system and signalling it to block incorrect data; implementation of scheduling confirmation through a specific form.

The fourth stage was to insert all the OPSM data in the system. The failure mode here was incomplete or incorrect data. The potential effects on the working process are the lack of authorization for the procedure ( $R=108$ points) and of correct materials for the surgery ( $R=450$ points). The related causes at this stage are inconsistent data provided by the physician and typing error by the scheduling assistant. For this stage, the initiatives taken have been described previously.

The fifth stage was the guidance of the doctor for patients to provide documents. The failure mode found was lack of information needed by the doctor. It resulted in no documents for the sector to check and forward them to both operator and supplier. The causes were forgetfulness, high workload or inexistence of a standard ( $R=24$ points). The foreseen initiatives to eliminate this failure were to create or adopt a standard form and determine that it be handed in to the hospital, to request the surgical scheduling in a timely manner.

The sixth stage was the receipt of all documents. The physician not forwarding the documents is the failure mode. The potential effect was not checking documents in the respective sectors and not forwarding them to both operator and supplier. The cause is the inexistence of a standard form and that it must be handed in to the hospital, to request surgical scheduling in a timely manner.
In the seventh stage, checking and correcting recorded information, the AG identified incomplete or incorrect data as failure mode. The effects are lack of authorization for the procedure ( $R=108$ points) and absence of correct materials for the surgery $(R=450$ points). The potential causes were inconsistent data provided by the physician and typing errors by the scheduling assistant. To minimize these failures, the suggestion was to hire professional nursing technicians to perform the surgical activity, create or adopt a standard form for scheduling and review data and parameters inserted in the computer system of the hospital.

The last stage of the OPSM process within the surgical scheduling sector is the referral of the request for authorization to perform the procedure to the health care provider. During the analysis of this stage, the AG pointed out the delay in meeting deadlines set by the health insurance as the main existing failure mode ( $R=96$ points). It is caused specially by out-of-date medical request for procedures and absence of specific documents. Both causes have the same effect on patient care, which is characterized by a lack of authorization for the procedure to be conducted. The suggested initiative was to establish an effective communication between the medical professional, the scheduling sector and the operator.

\section{The second stage of the process: OPSM Centre: pre-au- thorization area}

After analysing five stages, two failure modes with possible impacts on patient care, incorrect register and description of materials in the budget, we identified two primary causes: inadequate request by the hospital; and the supplier company that forwards the data based on the physician's background. The effects may result in lack of authorization to use materials ( $R=224$ points); $a b$ sence of the correct materials to perform the procedure $(R=320$ points); and incorrect authorization ( $\mathrm{R}=315$ points).

The initiatives to reduce these risks are those suggested for the correction of problems that involve medical requirements, materials record, referral and receipt of budgets and materials. We believe these initiatives are enough to severely reduce the care risk presented by the failure shown in this stage of the OPSM process.

\section{The third stage of the process: the assistance sector}

The assistance sector is responsible for many activities of the OPSM process. However, they were divided into two parts to better understand this process flow: before and after the operation of the logistic sector. Two stages were assessed in the first part of the activities carried out by the assistance sectors: from the receipt of the scheduling information with the authorizations and the request of the OPSM chosen for the surgery, to the supplier. We found three failure modes: the first, the material incorrectly registered in the system of the hospital ( $R=400$ points); the second, the information not available to the assistance sectors ( $R=49$ points); and the third, the inappropriate request for the material ( $R=200$ points). The potential effects involved are the incorrect, incomplete or wrong request for the material and its delay to the supplier. The initiative taken by the institution was a formal program to train professional to work with OPSM and the review of the database to select information. 
After the operation of the logistic sector, three stages were assessed: (a) to receive the OPSM and instruments; (b) to prepare the OPSM for use; and (c) to use the OPSM in the patient.

The failure mode at the stage (a) was the receipt of wrong or incomplete material; at (b) the incorrect or incomplete preparation of the materials; and at (c) the absence of adequate materials for the procedure to be conducted. The potential causes are directly connected to the failure modes. The causes represent a variable risk from 160 to 400 points.

The initiatives suggested were to hire skilled professionals for the work with OPSM and foment continuous education.

\section{The fourth stage of the process: the logistic sector}

The logistic sector of the OPSM centre is responsible for receiving, checking and forwarding materials to the assistance sectors. Two stages were analysed: receiving and checking the OPSM chosen for the surgery and forwarding OPSM and instruments duly registered for the destination assistance sectors.

We identified four failure modes in the stages: (a) to receive wrong or incomplete materials; (b) to forward wrong material to the assistance sector; (c) to forward materials to the wrong assistance sector; and (d) not to forward materials to the assistance sector. The failure modes are directly proportional to their causes, with varying risk from 16 to 120 points.

Among the several initiatives taken to reduce the causes and, therefore, the effect of these failures on patient care are: the review of registration of the OPSM in the system, the change and receipt of materials' information; the hiring of specialized technical professionals; and the continuous education of these professionals.

\section{DISCUSSION}

The FMEA is a widely accepted tool by the team when concerning patient's safety, because it allows the identification and prevention of failures to minimize the risks in assistance ${ }^{(10,12)}$.

The present study was conducted to analyse the failures in the working process of the OPSM. The objective was to develop strategies to reduce care risk. No high risk was identified. Nonetheless, some vulnerabilities have been identified in the care process of the OPSM, presenting failures that can happen at any stage of the flow chart. Some initiatives were implemented in the process to reduce possible risks. The written suggestions are also consistent with other studies that assessed safety in patient care $^{(13-15)}$, which is a priority for any health service.

When analysing the standardization of the OPSM register in the information system of the institution researched, we confirmed that the regulatory institution for the manufacturing and commercialization of OPSM in Brazil is the Brazilian Health Regulatory Agency (Agência Nacional de Vigilância Sanitária - ANVISA). This institution defines under the resolution $n^{\circ} 185^{(16)}$, that every medical, dental or laboratory product (also known as "health product" or "related product") can only be manufactured or imported after obtaining its registration along with the Ministry of Health. Although all the registration of materials that can be used and marketed on the national market, the supplier companies often use their own codification to identify and control the distribution and use of these materials ${ }^{(3)}$.

The National Regulatory Agency for Private Health Insurance and Plans (Agência Nacional de Saúde - ANS) implemented throughout the national territory, the Exchange of Information in Supplementary Health (EISH) to standardize the exchange of information in health and the nomenclature of procedures, materials, fees and services. This initiative standardizes the exchange of information and records between health insurance operators and service providers ${ }^{(17)}$. Therefore, a health institution that works actively and along with the OPSM must keep the records updated. This is a way to support professionals of the operational line in consults, to identify and register every receipt, to distribute and use the materials besides meeting requirements of the current legislation to ensure the patient's safety. Medical devices are not only plentiful. They also have a cutting edge technology and a short life cycle, and become quickly obsolete ${ }^{(18)}$. Despite their low consumption when compared to other medical products, the OPSM are expensive, and their purchase is neither regular nor large. They are often individualized by patient and medical preference ${ }^{(19)}$. There are hardly any identical materials and it is difficult for manufacturers to perform a technical comparison. To that end, ANVISA has created an inter-institutional work team to standardize the OPSM register, proposing restructuring measures and inducing the market (manufacturers and professionals) to correct irregularities ${ }^{(20)}$. This standardization may help to restructure one stage of the analysed process.

The AG discussed creating and adopting a specific form to request the OPSM so that it would represent a protocol or a checklist. The first step would be the physician's request and reach all stages of the process, from maintaining the information technology system, applying for budget and authorization, applying and receiving materials to preparing and using them in patient care.

ANVISA defines as checklist in health every list of verification created by specialists, which may help and support health teams to prevent harm to patients ${ }^{(17)}$. The use of this checklist, besides serving as a memory tool, allows assessing patients before, during and after each procedure. It also ensures that adverse events in operating and recovery rooms be effectively recorded by the team $^{(21)}$. The National Regulatory Agency for Private Health Insurance and Plans (ANS) suggests a standard form to develop a specific form for requesting and monitoring the OPSM. This form comes into effect along with all implemented initiatives with the $\mathrm{EISH}^{(20,22)}$. The standardization was established by the World Health Organization and implemented in several countries ${ }^{(23-24)}$. Another proposal to correct failures found in the OPSM process of the institution was to hire technical personnel in the field of surgical nursing to act in all its stages. In daily practice, hospital institutions must keep updated about the market and invest in highly-skilled labour, specific qualification for certain functions or tasks and personalized patient care and safety. Hence, it is virtually a daily challenge to manage and develop skills in these professionals, as well as to correctly evaluate them with the purpose of improving assistance outcomes ${ }^{(25)}$. On the other hand, failure in communication during the transfer of information may occur, since it involves humans and not only technology ${ }^{(10)}$. 
According to the Brazilian Association of Surgical Centre Nurses, Anaesthetic Recovery and Centre of Materials and Sterilization, it falls under the nurse's responsibilities to check the implantable materials necessary for the procedures and the availability and functionality of materials, instruments and equipment to perform the surgical procedure. The nurse from the material and sterilization centre must define the deadline to receive reprocessable products and what products are these. Nursing technicians in the surgical centre are responsible for checking all materials needed for the surgical procedure, their availability in an orderly manner and ensuring the records and traceability of the implantable products ${ }^{(26)}$. Thus, nursing professionals are today representatives for the workforce with the highest qualification, competence and security to act in the OPSM processes. They are capable both as leaders of stages and in the technical-operational activities.

A different proposal was to set up a permanent training head office, which would continuously train professionals that have functions in all stages of the intra-institutional work. They would also develop skills for mobilization in the work environment and their evolution in three specific dimensions: knowledge, skills and know-how and proactivity. These dimensions help professionals to safely develop their skills and keep up with the technological innovations ${ }^{(27)}$.

Permanent training represents a set of learning opportunities for professionals, providing mastery on specific knowledge for their function and resulting in better training, better performance and greater experiences. It all can be used daily to perform their activities. The challenge now is to make this dynamic a constant process, favouring shared practice and vision through structured programs focused on the needs of the professional, the company and the patient safety ${ }^{(27)}$.

Despite the complexity of the care process with OPSM, there is the possibility of errors, which not only generate irreversible costs to the institution and the health care insurance companies but also give rise to patient insecurities. After implementing the FMEA, error reduction can bring benefits to the system, ensuring a quality assistance with the least possible harm to the user.

\section{Study limitations}

Since the outcomes refer to a private and teaching hospital, it is important to be cautious when analysing other institutions, which may vary according to different contexts. Future studies are still needed to quantify other variables possibly related to adherence to the OPSM working process and to explain, more comprehensively, the variability in deployment success.

\section{Contributions to the nursing, health or public policy sectors}

The working process of managing OPSM, conducted by the nurse, is considered a high cost for the hospital. Therefore, this process must be thoroughly designed and strictly followed by the professionals involved. This should happen from entry control, preparation, conservation, use, return and invoicing materials.

\section{CONCLUSION}

We found that the FMEA strategy starts with good communication, aiming at improving the OPSM process and the patient safety. Although interventions have been performed and minimized errors in this process, communication still depends on people.

We believe that future studies could address the OPSM working process under the FMEA scope, with focus on costeffectiveness analysis. This would allow cross-referencing of information with the data of the present study, for a broader understanding of the impacts of this process in institutions.

\section{REFERENCES}

1. Hinrichsen SL, Possas L, Oliveira CLF, Ramos V, Vilella TAS. Failure Mode and Effects Analysis (FMEA) and the international patient safety goals: pilot study. RAS [Internet]. 2012 [cited 2017 Jan 12];14(57):151-60. Available from: http://www.cqh.org.br/ portal/pag/doc.php?p_ndoc $=515$

2. Siman AG, Brito MJM, Carrasco MEL. Participation of the nurse manager in the process of hospital accreditation. Rev Gaúcha Enferm[Internet]. 2014[cited 2017 Jan 12];35(2):93-9. Available from: http://www.scielo.br/pdf/rgenf/v35n2/1983-1447rgenf-35-02-00093.pdf

3. Nardino S, Dalcul AL, Gil P. Stock control of orthotics, prosthetics and special materials. Scienc Health [Internet]. 2011 [cited 2017 Jan 12];2(2):113-9. Available from: http://arquivos.cruzeirodosuleducacional.edu.br/principal/new/revista_scienceinhealth/05_ maio_ago_2011/science_113_119.pdf

4. Motta Filho GR, Silva LFN, Ferracini AM, Bahr GL. Protocolo de Cirurgia Segura da OMS: o grau de conhecimento dos ortopedistas brasileiros. Rev Bras Ortop[Internet]. 2013[cited 2017 Apr 24];48(6):554-62. Available from: http://www.scielo.br/pdf/rbort/ v48n6/0102-3616-rbort-48-06-00554.pdf

5. Stamatis DH. The ASQ Pocket Guide to Failure Mode and Effect Analysis (FMEA). American Society for Quality. Milwaukee: Quality Press; 2015.

6. Sawant A, Dieterich S, Svatos M, Keall P. Failure mode and effect analysis-based quality assurance for dynamic MLC tracking systems. Med Phys[Internet]. 2010[cited 2017 Jan 12];37(12):6466-79. Available from: http://online.medphys.org/resource/1/ mphya6/v37/i12/p6466_s1

7. Toledo JC, Amaral DC. FMEA: análise do tipo e efeito de falha[Apostila]. Grupo de Estudos e Pesquisa em Qualidade. UFSCAR; 2016. 
8. Brasil. Conselho Nacional de Saúde. Resolução n 466, de 12 de dezembro de 2012. Diretrizes e Normas Regulamentadoras de Pesquisas Envolvendo Seres Humanos. Diário Oficial da União, Brasília, DF, n. 12, 13 de junho de 2013. Seção 71, p. 59.

9. DeRosier J, Stalhandske E, Bagian JP, Nudell T. Using health care failure mode and effect analysis: the VA National Center for Patient Safety's prospective risk analysis system. Jt Comm J Qual Improv [Internet]. 2002[cited 2017 Apr 26];28(5):248-67. Available from: https://www.ncbi.nlm.nih.gov/pubmed/12053459

10. Johnston M, Arora S, Anderson O, King D, Behar N, Darzi A. Escalation of care in surgery: a systematic risk assessment to prevent avoidable harm in hospitalized patients. Ann Surg[Internet]. 2015[cited 2017 Apr 26];261(5):831-8. Available from: https://www. ncbi.nlm.nih.gov/pubmed/24887972

11. Nagpal K, Vats A, Ahmed K, Smith AB, Sevdalis N, Jonannsson H, et al. A systematic quantitative assessment of risks associated with poor communication in surgical care. Arch Surg[Internet]. 2010 [cited 2017 Apr 26];145(6):582-8. Available from: https:// jamanetwork.com/journals/jamasurgery/fullarticle/10.1001/archsurg.2010.105

12. Öhrn A, Ericsson C, Andersson C, Elfström J. High rate of implementation of proposed actions for improvement with the Healthcare Failure Mode Effect Analysis Method: evaluation of 117 analyses. J Patient Saf[Internet]. 2015[cited 2017 Mar 26];14(1)17-21. Available from: https://www.ncbi.nlm.nih.gov/pubmed/25719818

13. Zhu XW, You LM, Zheng J, Liu K, Fang JB, Hou SX, et al. Nurse staffing levels make a difference on patient outcomes: a multisite study in Chinese hospitals. J Nurs Scholarsh [Internet]. 2012 [cited 2017 Apr 26];44:266-73. Available from: http://onlinelibrary. wiley.com/doi/10.1111/j.1547-5069.2012.01454.x/abstract

14. Manger RP, Paxton AB, Pawlicki T, Kim GY. Failure mode and effects analysis and fault tree analysis of surface image guided cranial radiosurgery. Med Phys[Internet]. 2015 [cited 2017 Apr 26];42(5):2449-61. Available from: http://dx.doi.org/10.1118/1.4918319

15. Agência Nacional de Vigilância Sanitária. Anvisa. RDC n 185, de 22 de outubro de 2001: declaração, necessidade de atualizar os procedimentos para registro de produtos "correlatos" [Internet]. Nov 06, 2001[cited 2017 Apr 26]. Available from: http://adcon. rn.gov.br/ACERVO/Suvisa/doc/DOC000000000026336.PDF

16. Brasil. Ministério da Saúde. Agência Nacional de Saúde Suplementar. TISS 3.02.02-ANS. Padronização de Troca de Informações de Saúde Suplementar. 2016.

17. Brasil. Ministério da Saúde. Grupo de Trabalho Interinstitucional sobre órteses, próteses e materiais especiais (GTI-OPME). Relatório Final [Internet]. Brasília: MS; 2016[cited 2017 Apr 26]. Available from: http://www.ans.gov.br/images/stories/Particitacao_da_ sociedade/2016_gt_opme/gt-opme-relatoriointegral.pdf

18. Brasil. Ministério da Saúde. Secretaria de Atenção à Saúde. Departamento de Atenção Especializada e Temática. Manual de boas práticas de gestão das Órteses, Próteses e Materiais Especiais (OPME) [Internet]. Brasília: Ministério da Saúde; 2016 [cited 2017 Apr 26]. Available from: http://conitec.gov.br/images/Artigos_Publicacoes/Manual_PraticasGestao_OPME_2016.pdf

19. Agência Nacional de Vigilância Sanitária. Anvisa. Padronização de Nomenclatura de Dispositivos Médicos Implantáveis. Compatibilização MS-SIGTAP, Nomenclatura ANVISA, Nomenclatura ANS com a Nomenclatura GMDN. OPME (Órtese, Prótese e Materiais Especiais) [Internet]. 2016[cited 2017 Apr 26]. Available from: http://www.ans.gov.br/images/stories/Particitacao_da sociedade/2015_gt_opme/3reuniao_orteses_proteses_materiais_especiais_apresentacao_anvisa.pdf

20. Cullati S, Le Du S, Raë AC, Micallef M, Khabiri E, Ourahmoune A, et al. Is the Surgical Safety Checklist successfully conducted? an observational study of social interactions in the operating rooms of a tertiary hospital. BM] Qual Saf[Internet]. 2013 [cited 2017 Jan 12];22(8):639-46. Available from: http://qualitysafety.bmj.com/content/22/8/639.long

21. Freitas MS, Antunes AG, Lopes BNA, Fernandes FC, Monte LC, Gama ZAS. Assessment of adherence to the WHO surgical safety checklist in urological and gynecological surgeries at two teaching hospitals in Natal, Rio Grande do Norte State, Brazil. Cad Saúde Pública [Internet]. 2014 [cited 2017 Jan 15];30(1):137-48. Available from: http://www.scielo.br/pdf/csp/v30n1/0102-311Xcsp-30-01-00137.pdf

22. Walker IA, Reshamwalla S, Wilson IH. Surgical safety checklists: do they improve outcomes? Br J Anaesth [Internet]. 2012[cited 2017 Jan 15];109(1):47-54. Available from: https://academic.oup.com/bja/article/109/1/47/237109/Surgical-safety-checklists-do-they-improve

23. Aveling E, McCulloch P, Dixon-Woods M. A qualitative study comparing experiences of the surgical safety checklist in hospitals in high-income and low-income countries. BMJ Open[Internet]. 2013[cited 2017 Jan 15];3:e003039. Available from: http://bmjopen. bmj.com/content/3/8/e003039.citation-tools

24. Aued GK, Bernardino E, Peres AM, Lacerda MR, Dallaire C, Ribas EN. Clinical competences of nursing assistants: a strategy for people management. Rev Bras Enferm[Internet]. 2016[cited 2017 Mar 01];69(1):142-49. Available from: http://www.scielo.br/pdf/ reben/v69n1/en_0034-7167-reben-69-01-0142.pdf

25. Sociedade Brasileira de Enfermeiros de Centro Cirúrgico, Sala de Recuperação e Centro de Materiais e Esterilização. SOBECC. Práticas Recomendadas da Sociedade Brasileira de Enfermeiros de Centro Cirúrgico, Sala de Recuperação e Centro de Materiais e Esterilização. 6 ed. rev. e atual. São Paulo: Manole; 2013.

26. Salum NC, Prado ML. Continuing education in the development of competences in nurses. Texto Contexto Enferm[Internet] 2014[cited 2017 Jan 15];23(2):301-08. Available from: http://www.scielo.br/pdf/tce/v23n2/0104-0707-tce-23-02-00301.pdf

27. Camargo Tobias G, Queiroz Bezerra AL, Silvestre Branquinho NC, Camargo Silva AEB. Cultura de Segurança do paciente em instituições de saúde: um estudo bibliométrico. Enferm Glob[Internet]. 2014[cited 2017 Jan 15];13(33):336-48. Available from: http://scielo.isciii.es/pdf/eg/v13n33/pt revision1.pdf 